\title{
Hacking the code: una aproximació indagadora a lensenyament del codi genètic, o seguint les passes de Nirenberg i Khorana
}

Jordi Domènech Casal (jdomen44@xtec.cat) INS Marta Mata (Montornès del Vallès) i grup LIEC (Llenguatge i Ensenyament de les Ciències) de la Universitat Autònoma de Barcelona.

Es descriu el disseny i aplicació d'una activitat didàctica sobre el codi genètic, al llarg de tres eixos didàctics: l'aprenentatge per indagació, la naturalesa del coneixement científic $i$ la reflexió sobre els aprenentatges. L'activitat ressegueix l'estratègia dels experiments realitzats per Nirenberg $i$ Khorana per a descobrir el codi genètic i la seva aplicació mostra que és un bon punt de partida per a introduir el dogma central de la biologia molecular, que defensem que és un aspecte important de l'educació ciutadana dels nostres alumnes.

Paraules clau: indagació, ECBI, codi genètic, ADN, codó

The article presents a didactic activity about the Genetic Code, based on three methodologic principles: Inquiry-based science education, creation and nature of the scientific knowledge, and reflection on the learning process. The activity reproduces the strategy of the original experience developed by Nirenberg and Khorana. Results on the didactic application are discussed in the frame of the education for citizenship and show this strategy to be a good approach to introduce the topic of the central dogma of molecular biology in the school.

Keywords: inquiry, IBSE, genetic code, DNA, codon

\section{INTRODUCCIÓ}

L'ensenyament del Dogma Central de la Biologia Molecular[1] és un aspecte clau de la formació científica de l'alumnat, ja que constitueix un dels pilars de la biologia molecular. Però també és necessari per a la seva educació com a ciutadans, i per a fer intel-ligibles moltes de les notícies que llegim als diaris sobre mutacions, transgènics 0 teràpia gènica. En aquestes notícies es sol transmetre al lector un caràcter quasi-màgic de I'ADN (Àcid DesoxiriboNucleic) -quan no malèficque caldria combatre des de l'educació responent amb l'alumnat a una pregunta simple: com "fa" coses I'ADN?

El mecanisme biològic d'acció de l'ADN, i particularment, el codi genètic (que constitueix la clau de volta d'aquest tema), es troba present en els programes curriculars de diverses matèries i nivells de l'educació obligatòria i post-obligatòria (Biologia i Geologia a 4t d'ESO, Biologia a Batxillerat).

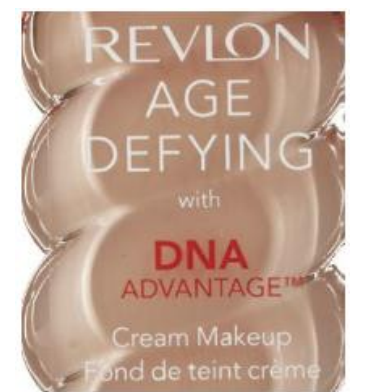

Figura 1.- La concepció errònia d'un ADN “amb poders" és aprofitada per empreses farmacèuti- 
ques i organitzacions pseudocientífiques, que exploten la imatge i identitat de l'ADN com a quelcom poderós i científic (per exemple, suggerint un paper cosmètic per acció directa de la mol.lècula o afirmant que la seva vibració es pot harmonitzar per a millorar la salut). Imatge extreta de la web productes farmacèutics Revlon.

Els llibres de text solen tractar el codi genètic de forma paral-lela 0 , pràcticament, com a conseqüència o concreció dels mecanismes biològics de transcripció i traducció, i amb poques mencions al procés del descobriment. L'alumnat sol rebre de forma paral-lela i passiva diversos conceptes molt complexos per si mateixos (la naturalesa del codi genètic, l'estructura de l'ARN transportador, la transcripció als ribosomes i la maduració de l'ARN missatger), representant un punt conflictiu en els temaris.

Les estratègies d'Ensenyament de les Ciències Basat en la Indagació (ECBI) promouen el protagonisme i l'interès de l'alumnat (Rocard, 2006) i el desenvolupament d'habilitats de raonament i actituds científiques (Caamaño, 2004 i 2012, Barolli et al, 2010, Llewellyn, 2005), mitjançant activitats investigadores que tenen una estructura estàndard (Bogner, Boudalis i Sotirou, 2012):

1) Formular preguntes investigables

2) Donar prioritat a l'observació

3) Analitzar l'observació

4) Formular una explicació basada en les observacions

5) Connectar l'explicació amb els models o coneixements científics

6) Comunicar i justificar l'explicació

7) Reflexionar sobre el procés.

Aquestes activitats tenen també un potencial molt important pel que fa a la naturalesa del coneixement científic, del que l'alumnat sol tenir un concepte excessivament rígid (ignorant-ne la naturalesa democràtica, creativa i serendípica). En el marc del projecte C3 sobre la Creació del Coneixement Científic [2], i amb l'objectiu de promoure una millor comprensió i interès de l'alumnat sobre el codi genètic, hem desenvolupat i testat una activitat d'indagació sobre el codi genètic a l'aula seguint la proposta ECBI i els experiments de Nirenberg i Khorana.

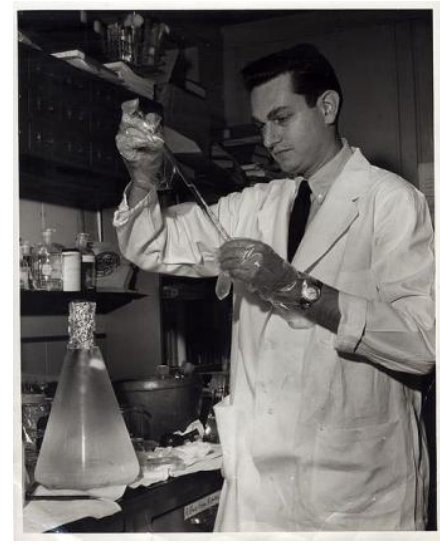

Figura 2.-Els investigadors Nirenberg i Khorana són cèlebres per haver descobert el codi genètic. Partint d'experiments anteriors d'altres investigadors (entre ells l'espanyol Severo Ochoa) van aplicar una estratègia aparentment senzilla: sintetitzar artificialment polinucleòtids d'ARN i veure quins pèptids resultaven de la seva traducció. Associant els resultats obtinguts amb diferents ARN sintètics, van trobar les pautes que configuren el codi genètic: cada triplet diferent de nucleòtids (codó) codifica per una informació, que pot ser un dels 20 aminoàcids que es coneixen o "inici de pèptid" o "fi de pèptid". A la imatge, Nirenberg treballant al seu laboratori. Imatge cedida al domini públic per WikiMedia Commons.

\section{DESCRIPCIÓ DE L'EXPERIÈNCIA}

L'activitat ha estat dissenyada i aplicada el curs 2012-2013 amb 18 alumnes de 4 d'ESO de I'INS Marta Mata (Montornès del Vallès) a la matèria de Biologia i Geologia de 4 ESO, que es realitza en anglès. Amb els alumnes no s'havia treballat prèviament en la matèria l'estructura de l'ADN, el codi genètic ni el dogma central de la biologia molecular, però estaven familiaritzats amb activitats ECBI prèvies realitzades a l'aula (Domènech, 2013, Domènech, 201?a). El treball es va distribuir en dues sessions en diverses etapes, que es descriuen a continuació juntament amb comentaris sobre els resultats didàctics de cada etapa. L'activitat i els materials s'ofereixen per a la seva descàrrega lliure a internet [3].

\section{Identificant pautes, fent hipòtesis, dissenyant experiments: Com funci- ona, això?}

Es distribueixen els alumnes en equips de tres alumnes. A cada equip se li proporcionen per escrit diverses seqüències d'ADN de 21 nucleòtids (només la cadena 5'-3') -diferents per a cada equip- i les seqüències de pèptid per les que codi- 
fiquen, expressades en codi de tres lletres (tipus Ala, Lys, Cys,...). A l'alumnat només se li demana que expliqui tot el que pugui sobre el codi que relaciona el text (ATCG,...) amb els missatges corresponents (Leu, Ala, Lys,...), però no se li explica què son aquestes seqüències, ni es menciona que es corresponguin a ADN o pèptids, simplement se'ls proposa resoldre un jeroglífic com a repte intel-lectual, sense donar cap més informació fins al final de l'activitat. No es permet l'ús d'ordinador, i els equips treballen de forma independent, anotant les seves observacions i conclusions, fins a la síntesi de l'activitat. Les seqüències d'ADN i pèptid no es proporcionen totes alhora, sinò que es van proporcionant seqüencialment, en etapes (d'una durada de 5 minuts) cadascuna.

Etapa 1) Es proporcionen tres seqüències d'ADN que no contenen codons sinònims ni Stop, i totes comencen per ATG (codó inici). Totes elles són codificants. Aquesta etapa exercita una habilitat científica important, com és la identificació de pautes i patrons a partir d'un conjunt desordenat de dades.

\section{ATGTTAGGTAGTAAAGATGCT \\ MetLeuGlySerLysAspAla \\ ATGCATGAAGCTATTTATGAT \\ MetHisGluAlalleTyrAsp \\ ATGGGTAGTGATGAAGCTTAT \\ MetGlySerAspGluAlaTyr}

Figura 3.-Exemples de seqüències que es donen a un equip a l'etapa 1. Les seqüències permeten descobrir que el codi és de tres lletres, i la identitat d'alguns dels codons. En aquesta primera etapa no s'usen codons sinònims (cada aminoàcid es codifica sempre de la mateixa manera). Els ombrejats, subratllats i negretes indiquen les identitats que es poden descobrir, i no són presents en el document que es dóna a l'alumnat.

Etapa 2) Les tres noves seqüències comencen també totes elles per el codó ATG (inici), i contenen almenys dos codons sinònims, cosa que posa en dubte algunes de les conclusions prèvies, tot i refermar-ne d'altres.

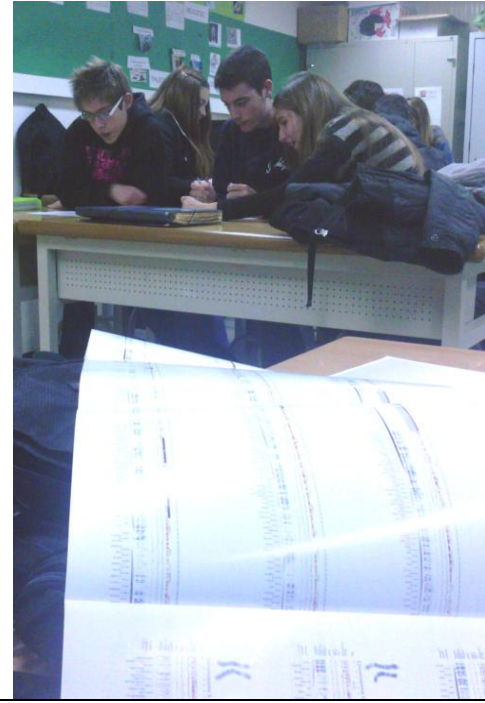

Figura 3.-Les activitats d'indagació compleixen una condició necessària per a aconseguir aprenentatge significatiu: suposen un repte intel-lectual en el que cal instrumentalitzar conceptes, habilitats $\mathrm{i}$ actituds. A la imatge, alumnes buscant pautes, argumentant i acordant idees que els ajudin a construir un model abstracte.

Etapes 3 i 4) En la tercera etapa, algunes de les seqüències no tenen el codó ATG a l'inici, o el tenen més endavant en la seva seqüència, implicant cadenes de pèptids més curtes o cadenes sense pèptid associat. En la quarta, algunes de les seqüències tenen un codó Stop que atura la lectura implicant també pèptids més curts. Aquestes etapes faciliten a l'alumnat el descobriment de la funció d'aquests codons, i completar identitats codó-aminoàcid.

\section{ATG \\ Met \\ TGTCTAATG \\ Met \\ ACCGGATTTGTCCAACGTTGC}

Figura 4.-Exemples de seqüències que es donen a un equip a l'etapa 3. L'alumnat hi descobreix que la posició del codó Inici (ATG), que ara apareix en altres posicions diferents de la primera, és indicativa d'inici de missatge (el marcat en negreta o gris no apareix en els materials que es proposen als alumnes). En totes les seqüències de totes les etapes els aminoàcids apareixen en codi de tres lletres. 
Etapa 5) Els alumnes poden demanar 4 mutacions, o canvis en les seqüències que ja tenen, per a testar les seves hipòtesis sobre el funcionament del sistema. Han de partir de les seqüències que ja tenen i dissenyar canvis que els permetin testar hipòtesis sobre la funció o significat de parts de les seqüències. El professor, sense mostrar el codi genètic, donarà en resposta quina seqüència tindria el pèptid resultant, i el alumnes confirmaran o descartaran les seves hipòtesis. Aquesta part de l'activitat obre la indagació, ja que permet que els alumnes dissenyin experiments per confirmar hipòtesis de la seva elecció.

\section{Argumentant i construïnt coneixe- ment: per què dius el que dius?}

Al final de l'activitat, cada equip presenta oralment els seus resultats a la resta de grups, que els contrasten amb els propis. A més d'explicar les hipòtesis a les que han arribat, els alumnes les han de justificar, explicant els experiments dissenyats $\mathrm{i}$ les seves conclusions i el rang de certesa de cada conclusió. Després de cada exposició, es decideix quines conclusions s'aproven de manera general. Quan una conclusió és acceptada per tots els alumnes, s'anota a la pissarra, representant l'acord de la comunitat científica. En l'aplicació, s'ha obtingut un codi genètic pràcticament complet, en el que mancaven pocs codons per traduïr. Els resultats no s'han contrastat amb un codi genètic real com a part de l'activitat, per tal de mantenir la idea del coneixement científic com un constructe.

Contrastar els resultats amb les dades d'un llibre no es correspon a l'experiència real dels científics, que no disposen d'un Ilibre on comparar les seves conclusions: aquesta sensació d'incertesa, o de coneixement provisional que caracteritza el coneixement científic es pot fomentar entre els nostres alumnes si evitem quan sigui possible confirmar els resultats de les activitats d'indagació amb manuals o llibres. L'educació científica ha d'ajudar a gestionar la incertesa, més que no pas transmetre certeses.

\section{Reflexionant sobre el procés: com saps el que saps?}

Un cop consensuat el codi genètic, s'ha discutit amb l'alumnat en diàleg obert a l'aula de quina manera han arribat al coneixement, partint d'una llista de preguntes al voltant de l'experiència.

- Has parlat amb algú durant el procés?

- Has comprovat el que deies d'alguna manera?
- S'ha arribat en algun moment a conclusions contradictòries/complementàries? Com s'ha resolt?

- Totes les conclusions han estat igual de sòlides? Com ho has fet per a millorar-ne la solidesa?

- Has descobert alguna cosa nova seguint una proposta d'algú altre?

- ...

Com a tancament de l'activitat, el professor ha explicat als alumnes que les seqüències amb les que han treballat són seqüències d'ADN i proteïna, que el codi que han descobert és el codi genètic. També ha descrit la recerca original de $\mathrm{Ni}$ remberg i Khorana (Nirenberg et al, 1965), en la que aquests dos investigadors van descobrir el codi genètic per estudis d'associació entre seqüències d'ARN $i$ els seus pèptids corresponents, és a dir, en un exercici d'identificar pautes molt similar al realitzat per l'alumnat. En una sessió posterior, el professor ha explicat com a classe magistral el Dogma Central de la Biologia Molecular (processos de transcripció i traducció).

\section{VALORACIÓ DE L'EXPERIÈNCIA}

L'activitat segueix un esquema d'indagació que es va obrint paulatinament: partint d'un objectiu determinat pel professor, els alumnes apliquen estratègies de la seva elecció per a completar la seva recerca, fins arribar a una activitat d'indagació oberta on poden dissenyar experiments (en la forma de mutacions) que els permetin testar les seves hipòtesis. L'activitat ha promogut el desenvolupament de diverses habilitats fonamentals per al desenvolupament de la competència científica (modificada de Pedrinacci et al, 2012):

- Identificar pautes

- Construir Hipòtesis

- Dissenyar experiments

- Extreure conclusions de dades incompletes

- Establir rangs de certesa de les conclusions

- Comunicar i argumentar científicament

Aquesta habilitats s'han anat exercitant en les diferents etapes: en la primera etapa, per exemple, tots els alumnes han estat capaços de determinar que existeix un codi de tres lletres que relaciona les seqüències text amb les seqüències missatge, descobrint el concepte de triplet, o codó, el que exercita l'habilitat d'identificar pautes. Tots els equips són capaços d'identificar algunes identitats codó-aminoàcid. En la segona etapa, l'aparició de codons sinònims ha generat un cert nerviosisme entre l'alumnat, i creiem que és es- 
pecialment important perquè s'experimenti quelcom important en la creació del coneixement científic: l'aparició d'algunes dades que entren en conflicte amb el model no necessàriament vol dir que calgui descartar el model, potser simplement s'ha de fer menys restrictiu o cal desfer algunes assumpcions. Això exercita les habilitats d'extreure conclusions de dades incompletes i d'establir el rang de certesa de les conclusions.

L'adquisició de competència científica va més enllà de l'adquisició d'habilitats d'anàlisi, i implica també l'adquisició de models científics i actituds científiques (Pedrinacci et al, 2011). En l'activitat, els alumnes milloren la seva comprensió dels conceptes de codó, codó sinònim i dels efectes i naturalesa de les mutacions. Partint del treball realitzat en l'activitat, ha estat més senzill explicar a la sessió següent a el Dogma Central de la Biologia molecular, que ha donat a l'activitat la base química necessària per a entendre la naturalesa material (i no mística) de l'acció de I'ADN. La introducció posterior de l'ARN en el sistema pot ser una mica confusa per l'alumnat, que ha treballat en l'activitat només amb ADN i pèptid. En tot cas, realitzar a continuació d'aquesta una altra activitat d'indagació resseguint els coneguts experiments de Griffith per a identificar I'ADN com a material hereditari (ampliant $\mathrm{i}$ analitzant dades de medis amb combinacions de ADNassa, ARNassa i Proteassa), podria ser una bona opció perquè l'alumnat identifiqués l'ARN com a pas intermedi. La relació d'aquesta part de la genètica (mecanisme d'acció de la informació genètica) amb l'estructura de l'ADN

És important tenir en compte que -degut als exercicis i representacions que fem els professors a l'aula- l'alumnat té tendència (no només en aquesta activitat, sinó de forma general en l'ensenyament de la genètica molecular) a creure que la mida habitual de les proteïnes és de 6-7 aminoàcids. Convé tenir-ho en compte per a corregir aquesta concepció errònia, ja que podria ser involuntàriament reforçada en aquesta activitat.

El model de l'activitat de formar diversos equips que treballen per separat, però que construeixen models mitjançant la comunicació i l'argumentació transmet a l'alumnat un model sobre la creació del coneixement científic, un aspecte a potenciar com a part de la competència científica. En l'aplicació, tot i que es pretenia que la informació dels diferents grups es complementés, s'ha vist que l'alumnat té tendència a competir entre grups, i és interessant discutir en l'última etapa l'equilibri competència/col-laboració que existeix en el món real de la recerca científica, i discutir quins elements de pressió (beques, projectes,...) tenen influència en la generació de competència $i$ de biaixos científics, sotmetent interessos i perspectives científiques a altres perspectives (socials, econòmics, ....).

El diàleg al voltant de les preguntes finals, a més de promoure l'argumentació, ha resultats en situacions que s'han discutit en aquest marc, fent també atenció a com s'ha sentit cadascú:

- un grup ha intercanviat informació amb un altre grup, però sense donar tota la informació que tenia.

- a un grup li ha tocat parlar a la sessió final quan ja els altres ho havien dit tot.

- les dades d'una etapa han servit per a reconsiderar les conclusions que s'havien obtingut en una etapa anterior.

Com a revisió de l'aplicació, pensem que es podria obrir més el disseny de l'activitat, si enlloc de dir a l'alumnat que existeix un codi que han de buscar, se'ls donen simplement les parelles ADN-pèptid i se'ls demana que descobreixin tot el que puguin, de manera que hagin fins $i$ tot de descobrir la mateixa existència d'un codi (la capacitat de trobar pautes i l'actitud de buscar pautes són dos elements competencials diferents). Incloure-hi seqüències irrellevants 0 seqüències corresponents d'ARN són també opcions que considerem. Ampliar l'activitat amb activitat posteriors sobre les pautes de lectura (ORF), el codon usage o l'enginyeria genètica és una possibilitat a estudiar per a alumnes de batxillerat.

Tot i que seria relativament senzill proposar l'activitat en entorn digital amb traducció automàtica de seqüències, creiem que el format de treball de paper i bolígraf és un format útil, perquè activa el treball d'identificació de pautes, dóna més rellevància a les estratègies de l'alumnat i obre més possibilitats d'aplicació a l'aula i de dinàmiques d'interacció entre companys. Així mateix, malgrat que els formats d'activitats manipulatives i mediades per ordinador presenten avantatges en les activitats d'indagació (Domènech, 201 ?b), el format de paper i bolígraf facilita l'adaptació de l'activitat per part del professor sense necessitat de coneixements específics.

\section{REFERÈNCIES}

BAROLLI, E., LABURÚ, C.E., GURIDI, V. M. (2010). Laboratorio didáctico de ciencias: caminos de investigación. Revista Electrónica de Enseñanza de las Ciencias 9, 88-110

BOGNER, Franz, BOUDALIS, Athanassios, SOTIRIOU, Sofoklis. (Eds.) (2012). Pathway. Best 
Practices of Inquiry-Based Science Education. Methods and Activities. Epinoia, Pallini Attikis, Greece.

CAAMAÑO, Aureli (2012). ¿Cómo introducir la indagación en el aula? Los trabajos prácticos investigativos. Alambique, Didáctica de las Ciencias Experimentales, 70, 83-91.

CAAMAÑO, Aureli (2004). "Experiencias, experimentos ilustrativos, ejercicios prácticos e investigaciones: Una clasificación útil de los trabajos prácticos?" Alambique, Didáctica de las Ciencias Experimentales, 39, 8-19.

DOMĖNECH, Jordi (2013). Les Mistery boxes: una activitat senzilla d'indagació a l'aula com a metàfora de la ciència. Ciències, 24, 20-25.

DOMÈNECH, Jordi (201?a). Caminalcules: una secuencia didáctica de indagación y comunicación científica sobre taxonomía, evolución y estratigrafía. Alambique: Didáctica de las Ciencias Experimentales, en avaluació.

DOMÈNECH, Jordi (201?b). Indagación en el aula mediante actividades manipulativas y mediadas por ordenador. Alambique: Didáctica de las Ciencias Experimentales, acceptat, en edició.

LLEWELLYN, D. (2005). Teaching High School Science through Inquiry: A case study approach. Corwin Press \& NSTA press.

NIRENBERG M., LEDER P, BERNFIELD M., BRIMACOMBE R., TRUPIN J., ROTTMAN F., O'NEAL, C. (1965). RNA codewords and protein synthesis. On the general nature of the RNA code. Procceedings of the National Academy of Sciencies U.S.A. 53(5): 1161-8.

PEDRINACCI, E., CAAMAÑO, A., CAÑAL, P., DE PRO, A. (2012). 11 ideas clave. El desarrollo de la competencia científica. Graó, Barcelona
ROCARD, M., CSERMELY, P., JORDE, D., LENZEN, D., WALWERG-HERIKSSON, H., HEMMO, V. (2006). Science Education Now: a new pedagogy for the future of Europe. Report for the European Comission.

[http://ec.europa.eu/research/sciencesociety/document_library/pdf_06/report-rocard-onscience-education_en.pdf]

\section{AGRAIIMENTS}

Experiència realitzada en el marc del treball de recerca del grup LIEC (Llenguatge i Ensenyament de les Ciències) del Departament de Didàctica de la Matemàtica i les Ciències Experimentals de la Universitat Autònoma de Barcelona, grup de recerca consolidat (referencia 2009SGR1543) per I'AGAUR (Agència d'Ajuts Universitaris i de Recerca) i finançat per la Dirección General de Investigación, Ministerio de Educación y Ciencia (referència EDU-2012-38022-C02-02).

\section{NOTES}

[1] El Dogma Central de la Biologia Molecular estableix que la informació genètica conservada a I'ADN és transcrita a una molècula portadora d'informació, I'ARN, i finalment traduïda -seguint el codi genètic- a proteïna, que és qui realitza la funció codificada en l'ADN.

[2] El projecte C3 té per objectiu la creació d'activitats i aproximacions didàctiques que emulin els passos de creació del coneixement científic. https://sites.google.com/a/xtec.cat/c3/home

[3] https://sites.google.com/a/xtec.cat/hackingthe-code/ 